\title{
Anthropogenic causes of wetland loss and degradation in the lower Kłodnica valley
}

\author{
(southern Poland)
}

\author{
Krzysztof J. Wójcicki, Beata Woskowicz-Ślęzak
}

Department of Reconstructing Environmental Change, Faculty of Earth Sciences, University of Silesia, Będzińska Str. 60, 41-200 Sosnowiec, Poland

E-mail address: (corresponding author): krzysztof.wojcicki@us.edu.pl

\begin{abstract}
Loss and degradation of wetlands is now one of the most important environmental issues on a global scale. Previous research based on analyses of cartographic materials allow for quantification of changes in wetland area in recent centuries. The results of lithological research of peat cores, reported in this publication, have established that the processes of anthropogenic loss of wetlands can be much older and in the Kłodnica valley were initiated in the first millennium BC. As a result of increased mineral sedimentation accompanying soil erosion some peatlands have been fossilized whilst the area of others has been reduced. In total, the surface area of peat-forming wetlands in the bottom of the Kłodnica valley decreased by over $60 \%$ between the time of the Lusatian Culture settlement and the Middle Ages. Post-peatland habitats are recently used for agricultural or colonized by non-peat forming vegetation. These processes have played a more important role in the degradation of peatland ecosystems than the direct human impact in historic times. Changes in hydrographic networks, land drainage and regulation of water levels in rivers and canals in the last century have contributed to further reducing the wetland areas by almost $50 \%$ compared to the 1880 s. These processes, however, have mainly affected ephemeral non-peat forming wetlands.
\end{abstract}

KEY WORDS: peatland loss, hydrological changes, human impact, macrofossil analysis, upper Odra River basin

\section{Introduction}

Loss of wetlands is one of the most pressing and yet poorly recognised ecological problems of the modern world. This is due to the many functions performed by these ecosystems and the risks associated with their degradation. Wetlands are wildlife habitats responsible for increasing local biodiversity. They regulate and supplement groundwater resources, contribute to reducing the risk of flooding, purify water by intercepting pollution, stabilise the shoreline, moderate the local climate and are also used by man for agriculture and recreation. The degradation of wetlands leads to the release of greenhouse gases, especially $\mathrm{N}_{2} \mathrm{O}$ and $\mathrm{CO}_{2}$ (CHARMAN, 2002).

Therefore, the scale of degradation of wetlands must give rise to serious concern. The global reach of wetlands, according to the latest estimates (DAVIDSON, 2014), fell in the $20^{\text {th }}$ c. by $64-71 \%$.
In various regions of the world, this decline varies from 30 to 90\% (JUNK ET AL., 2013). About twothirds of the wetlands that existed in Europe 100 years ago have been lost (SILVA ET AL., 2007). Moreover, these processes have been intensifying. According to current estimates, between 1950 and 2008 the world could have lost $50 \%$ of its wetlands (LEADLEY ET AL., 2014; GARDNER ET AL., $2015)$. Since the 1950 s around $84 \%$ of peat soils have been lost in the UK and 57\% in Germany. Over the last 30 years Lithuania has lost $70 \%$ of its wetlands (SILVA ET AL., 2007). Unfortunately, the results of research in Poland indicate similar trends. Case studies show that the amount of wetlands lost in recent decades or centuries ranges from 34\% in the Orawa-Nowy Targ Basin ( 2006), slightly over 35\% in the Dobrzyń Lake District (KOPROWSKI ET AL., 2012) and 37\% near Olsztyn (CZACHOROWSKI, 1995), to over 75\% in the catchments of the Pilica and Warta in Central 
Poland (OlaczeK ET AL., 1990) and over 90\% in the Niepołomice Forest area (Jucha, 2014). The first step to stop these negative trends should be recognition of the state and local circumstances of the degradation of wetlands in Poland. In particular this applies to areas such as the upper Odra River basin, where such studies have not been conducted. The aim of the study reported in this publication was to determine the conditions and scale of the wetland loss and degradation in the lower River Kłodnica valley.

\section{Study area}

The study was conducted in the lower section of the Kłodnica valley within the Racibórz Basin (Fig. 1). According to geographic information system focused on Polish wetlands (SYSTEM INFORMACJI PRZESTRZENNEJ O MOKRADŁACH POLSKI, 2006) peatlands cover about $1.1 \%$ of the region, while non-peat forming wetlands occupied an area several times larger. Field studies have shown, however, that these data require updating. The formation of wetlands in the Kłodnica valley was mainly the result of the favourable pattern of the geomorphological and lithological factors. The latter include the presence of poorly permeable sediments: Miocene clays in the distal zone (KoTLICKI \& KOTLICKA, 1980) and Late Holocene overbank sediments in the proximal zone of the floodplain (WóJCICKI, 2010). The conversion of dry land to wetland depends strongly on geomorphological factors: primarily the formation of floodplain depressions (oxbow lakes, flood basins) and obstruction of the outflow in the progradation zones of alluvial fans. In the Late Vistulian, lateral migration of "big meanders" contributed to the development of steep erosion edges on the valley sides, favouring waterlogging due to groundwater seepage. In the Late Holocene, the development of wetlands might also have been contributed to by human economic activity. Especially in recent centuries, the valley bottom has been anthropogenically transformed due to the construction of the Kłodnica Canal (turn of the $18^{\text {th }}$ and $19^{\text {th }}$ centuries) and the Gliwice Canal (1930s) as well as large-scale exploitation of river sands.

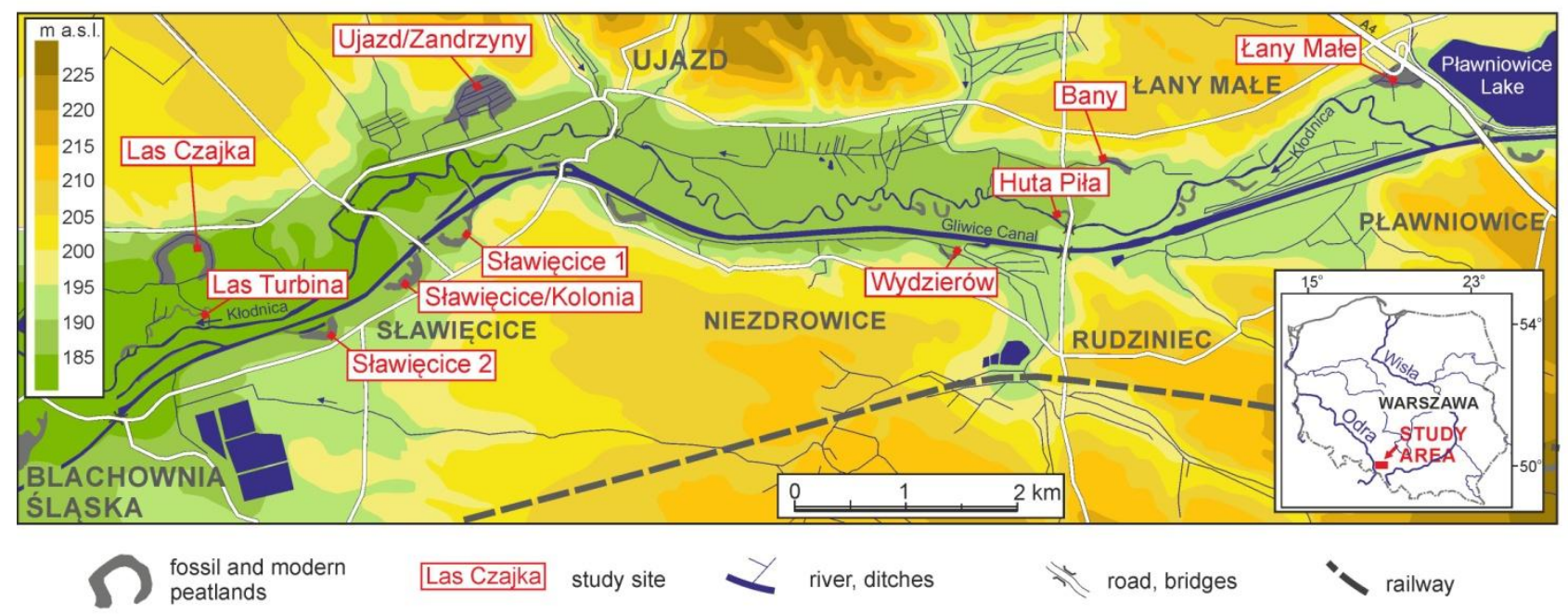

Fig. 1. Location of peatlands and study sites in the lower Kłodnica valley between Blachownia Śląska and Pławniowice

\section{Materials and methods}

The reconstruction of the surface area changes of wetlands in the Kłodnica valley was based on two independent research approaches. Shortterm trends (century scale) were determined on the basis of cartographic materials. Topographic maps at the scale of 1:25 000 were used, namely German maps from the 1880s and Polish maps from the late $20^{\text {th }}$ century. They were used to compare the extent of the areas marked as waterlogged, including both peatlands and nonpeat forming wetlands.
Long-term trends (Holocene scale) were identified only for the wetlands undergoing peat-forming processes. The reconstruction of the extent of peatlands was based on identifying organic deposits containing remains of organisms associated with the aquatic or telmatic environment (Fig. 2). The bioindicators were plant remains (including epidermis as well as fruits and seeds of hydroand helophytes) and chitin remains of aquatic arthropods identified in the course of the macrofossil analysis (WóJCICKI \& KLOSS, 2008; WóJCICKI, 2013). The extent of organic sediments was based on the interpretation of the orthophotomap at the scale 
of 1: 10 000. The results of the analysis of aerial photographs for fossil deposits were verified in the course of geological drilling. Geochronology of organic accumulation was based on the results of the radiocarbon dating, with the support of the pollen chronology as well as information from written sources.

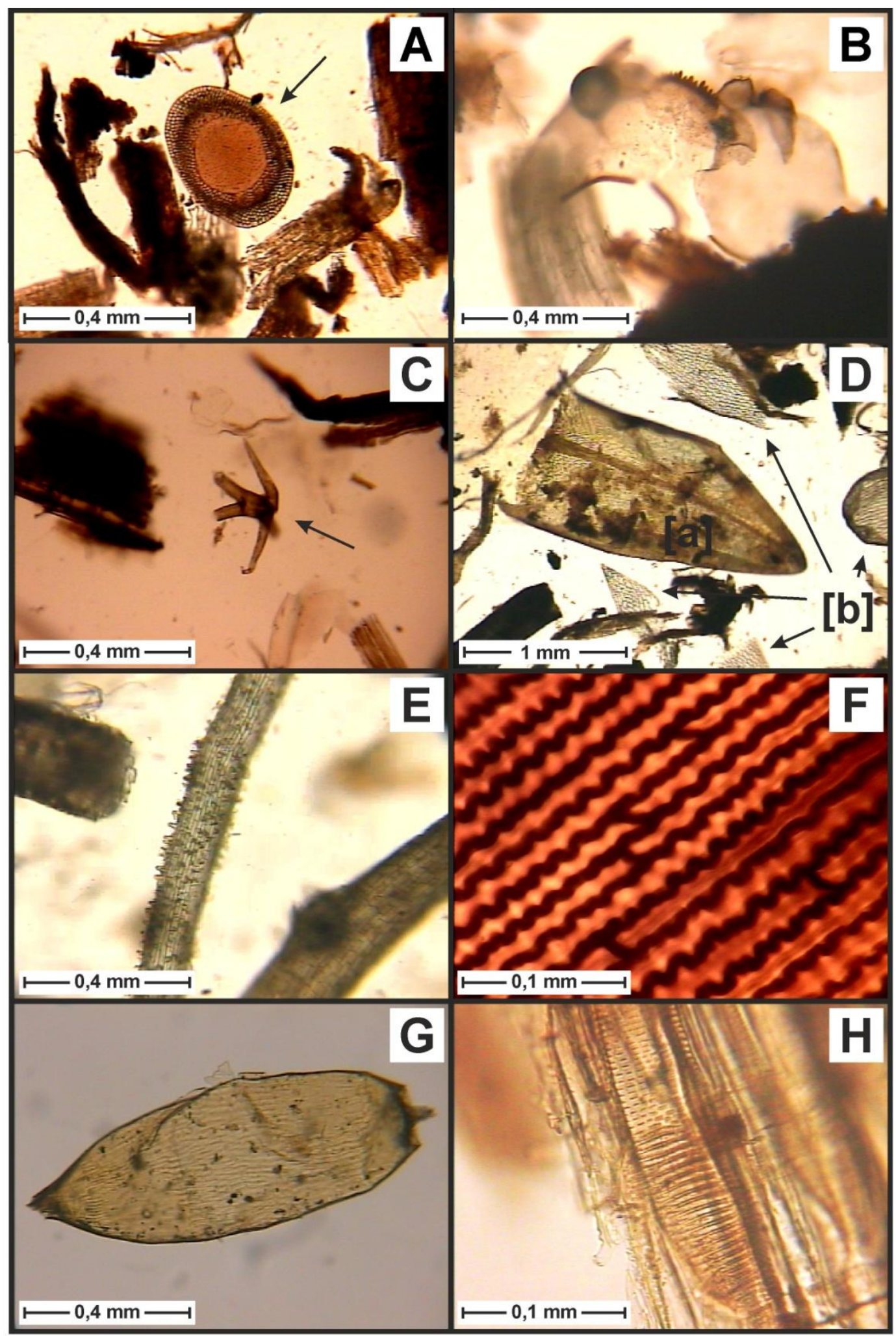

Fig. 2. Examples of macrofossils - bioindicators of the wetland environment noted in the cores analysed. Bioindicators of aquatic conditions: A - Bryozoa statoblast (Ujazd/Zandrzyny), B - Chironomidae head capsule (Las Turbina), C Nymphaeaceae idioblast (Sławięcice 2). Bioindicators of fen and swamp environments: D - brown moss (Calliergon sp.) [a] and Sphagnum sp. [b] leaves (Sławięcice 1), E - Cyperaceae roots (Sławięcice 1), F - Equisetum epidermis (Sławięcice 2), G Typha cf angustifolia seed (Łany Małe), H - Alnus glutinosa wood (Sławięcice 2) 


\section{Results}

\subsection{Development of peat-forming wetlands in the Holocene}

In the Kłodnica valley between Pławniowice and Blachownia Śląska 14 sedimentary reservoirs containing organic sediments with a thickness of over $30 \mathrm{~cm}$ have been identified. They occupy a total area of approximately 39 ha, which represents about $2.8 \%$ of the valley bottom. Peat-forming wetlands in the Kłodnica valley can be divided into fossil and active. The first group includes sedimentary reservoirs filled with organic sediments and then covered by a thick series of mineral deposits. As a result, peat-forming processes have been permanently stopped. This group includes the oldest, relatively extensive (8-12 ha) peatlands of the distal zone of the floodplain, as well as small (0.2-0.5 ha) Middle- and Late-Holocene forms of the proximal floodplain. The total area of these peatlands in the studied section of the Kłodnica valley is over 23 ha.

The domination of limno-telmatic conditions within the fossil peatland Ujazd/Zandrzyny (Fig. 3a) is indicated by the remains of Phragmites australis, Carex spp. and hygrophilous mosses (e.g. Limprichtia revolvens, Scorpidium scorpioides) as well as aquatic molluscs and Cladocerans (WójCICKI, 2013). According to radiocarbon dating, the mire was probably developing since the turn of the Allerød and Younger Dryas until the subAtlantic phase of the Holocene. The reason for the discontinuation of its development was progradation of the alluvial fan at the mouth of the loess gorge. Gradual reduction of the peatland surface area, initiated at the time of the Lusatian Culture settlement (Klimek, 2003), led to its disappearance in the historical period. According to the oral tradition, a mixture of calcium carbonate and organic matter was subjected to extensive extraction in the historical period. Nevertheless, the main cause of the total fossilisation of the fen was an increase in sedimentation rate associated with soil erosion. Similar factors determined the development of fossil mire at the Bany site where the covering of peat by sandy-silty slope deposits was initiated approximately $540 \pm 60{ }^{14} \mathrm{C}$ yrs BP (WójCICKI, 2010).

The analysis of sediments of a vast peatland in Łany Małe (Fig. 3b) showed its two-stage development. The earlier phase was dominated by forest communities (with prevailing Alnus glutinosa), while sedge communities developed during the younger stage of plant succession (WóJCICKI \& KLOSS, 2008). In the light of the results of the pollen analysis, the mire development was initiated in the pre-Boreal period (NITA \& WóJCICKI, 2005). Peat accumulation was finally halted ca. $1720 \pm 80{ }^{14} \mathrm{C}$ yrs BP. This correlates with the beginning of the activity of the Przeworsk culture settlement. At that time, the fen was subject to frequent flooding by water carrying fine suspensions derived from soil erosion of a nearby plateau. In recent years, the peat deposit has been degraded due to drainage works associated with the construction of the A4 motorway junction.

The depressions of the Wydzierów and Las Turbina palaeomeanders are not swampy today. Aquatic conditions prevailing in the past in the Wydzierów core (Fig. 3c) are documented by the remains of the epidermis of aquatic plants (e.g. Potamogeton spp. and Ceratophyllum sp.), accompanied by chitin shells of Cladocera. In the light of the radiocarbon dating, organic accumulation at this site could have already been interrupted during the Atlantic phase of the Holocene due to intense flood sedimentation. The prevalence of limno-telmatic conditions at the site of Las Turbina (Fig. 3d) is indicated by organic sediments showing a high proportion of remains of aquatic arthropods (WóJCICKI, 2013). In the light of radiocarbon dating, at the first stage their accumulation coincided with the middle part of the sub-Boreal phase and was resumed in the middle sub-Atlantic. The disappearance of the mire resulted from the sedimentation of sandysilty alluvia. The interruption of peat-forming processes between ca. 3.37 and $1.95 \mathrm{ka}{ }^{14} \mathrm{C}$ yrs BP was temporary. The disappearance of the peatland in the late Medieval Ages turned out to be permanent. Similar causes determined the wetland loss at the Huta Piła site (Fig. 3e). Organic deposits identified in this core contain, among others, bioindicators of the aquatic environment in the form of chitin remains of Cladocera and Chironomidae larvae. The history of the wetland was short, probably limited only to the middle part of the sub-Atlantic phase. In the early Medieval Ages (from about $1215 \pm 70{ }^{14} \mathrm{C}$ yrs BP) sedimentation of the silty-sandy alluvia increased which was responsible for the complete disappearance of the wetland.

The second group of the studied wetlands includes 8 active fens and swamps, whose surface is at most partly covered by mineral deposits. Nevertheless, the supply of silty sand sediments proved to be too small to stop the peat-forming processes. This group includes small (0.3-0.5 ha) contemporarily overgrowing oxbow lakes in the proximal zone and medium-sized (1.5-4.5 ha) objects located in the distal zone of the floodplain. 
The examples of forms, whose surface area has been somewhat limited under the influence of human activity, include the sites of Sławięcice 1 and Sławięcice 2. The peatlands whose original area was not significantly reduced in the subAtlantic phase include, among others, the sites of Las Czajka and Sławięcice/Kolonia.

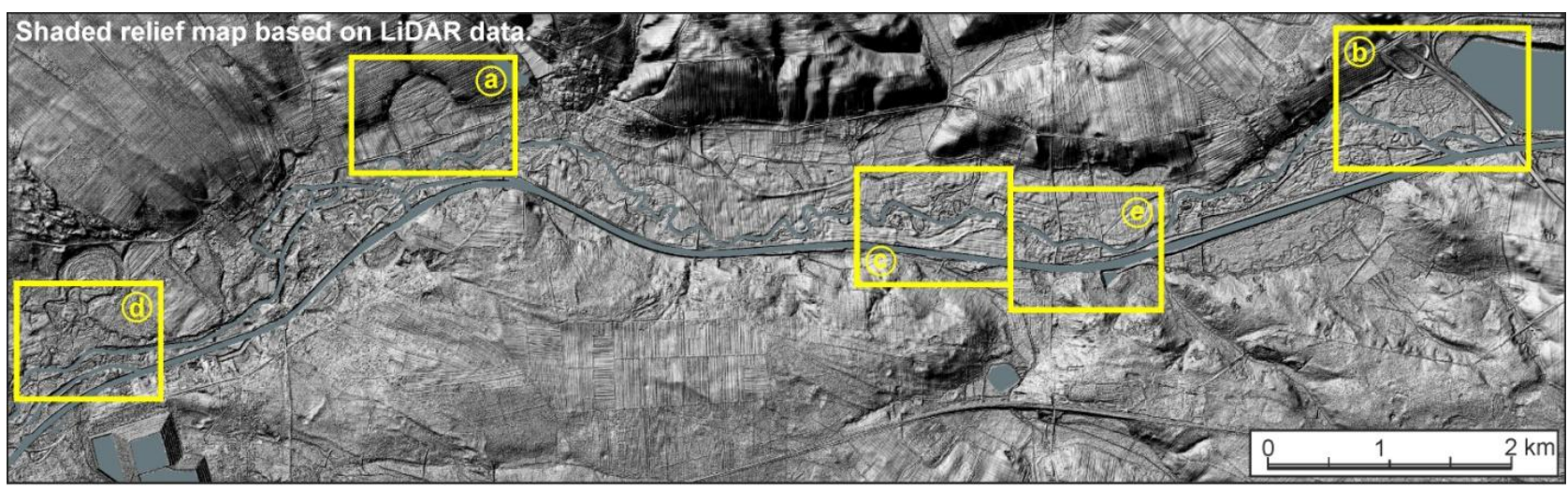

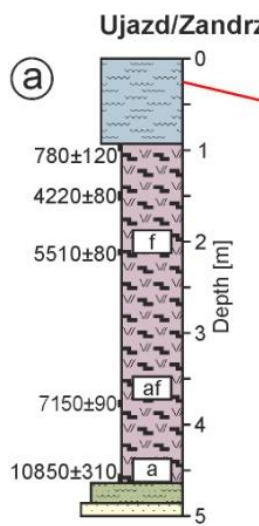
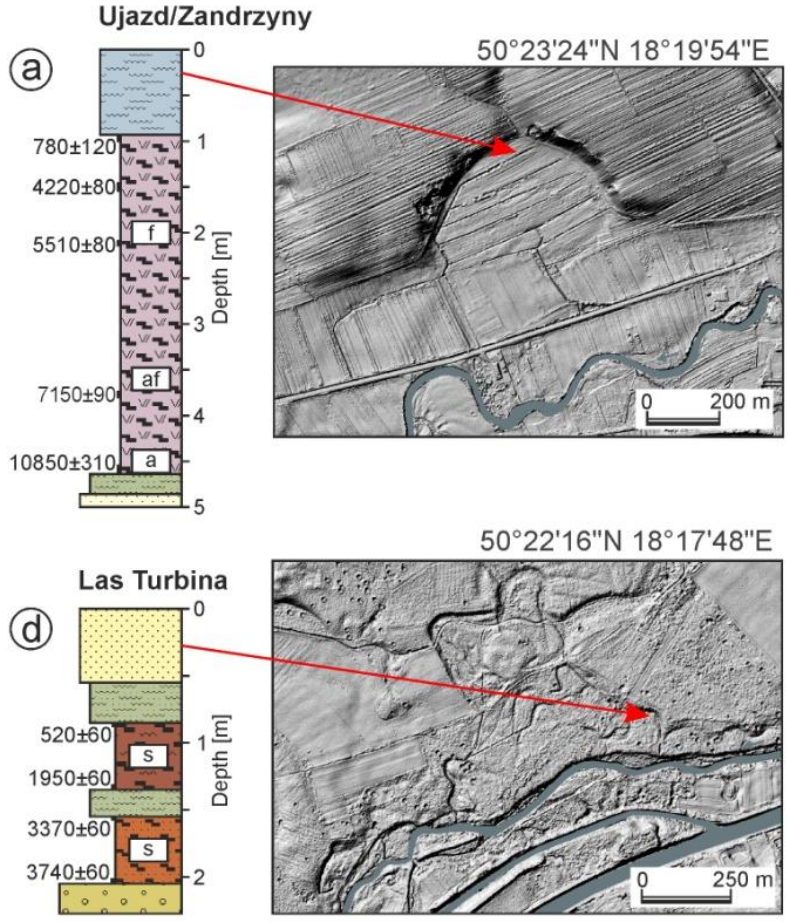

Stage of peatland development: main components of organic deposits:

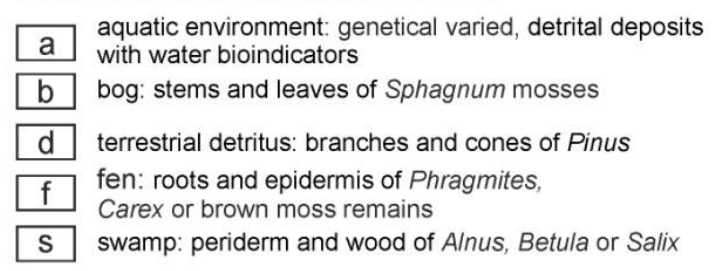

Deposits:

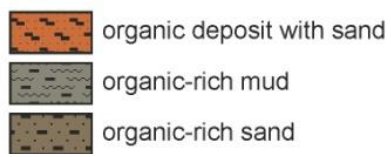

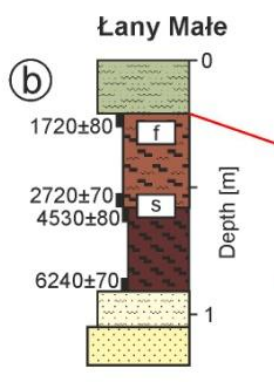
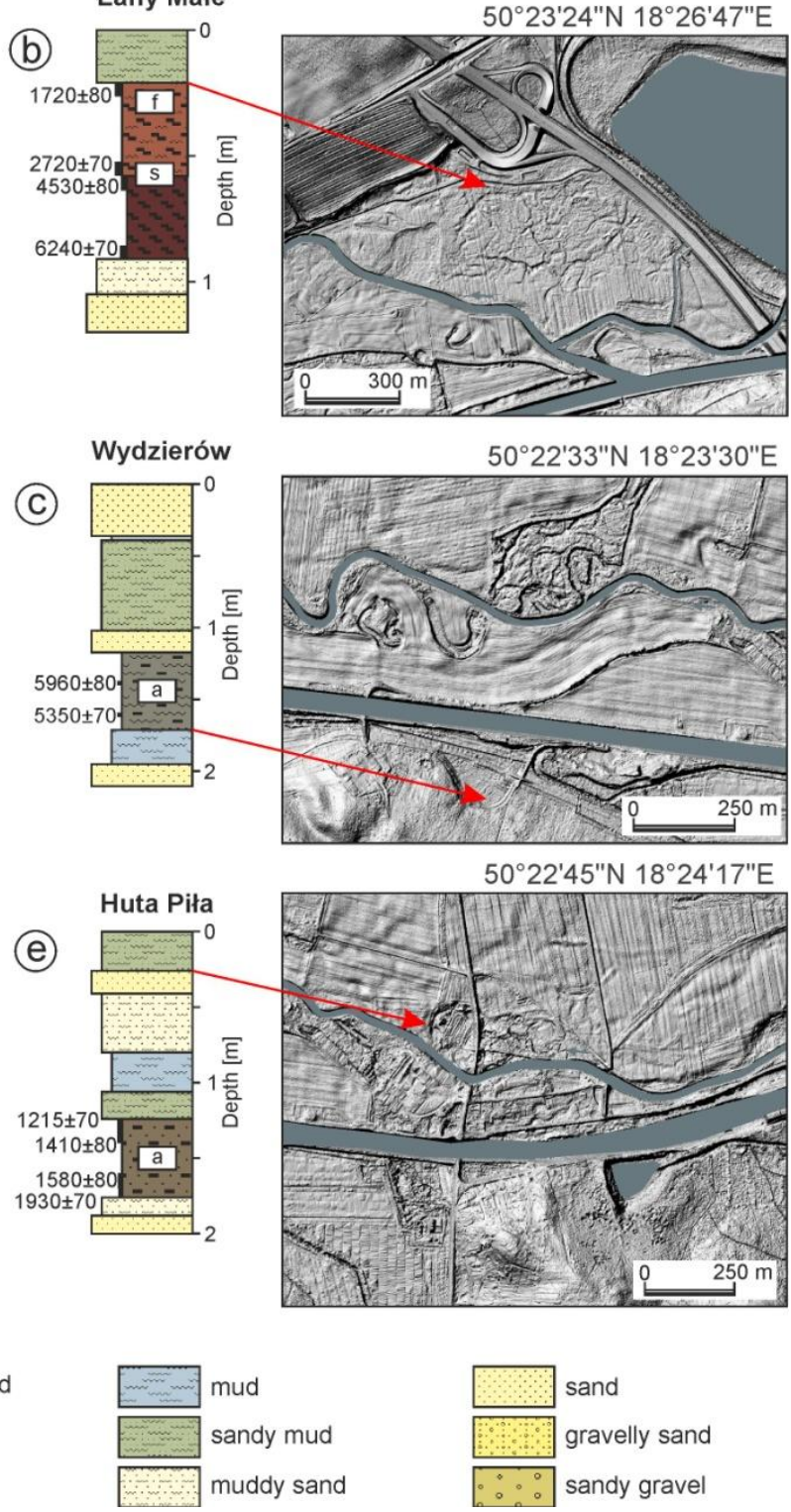

Fig. 3. Radiocarbon-dated sequences of the fossil wetland deposits (shaded relief map based on LiDAR data from CODGiK) 

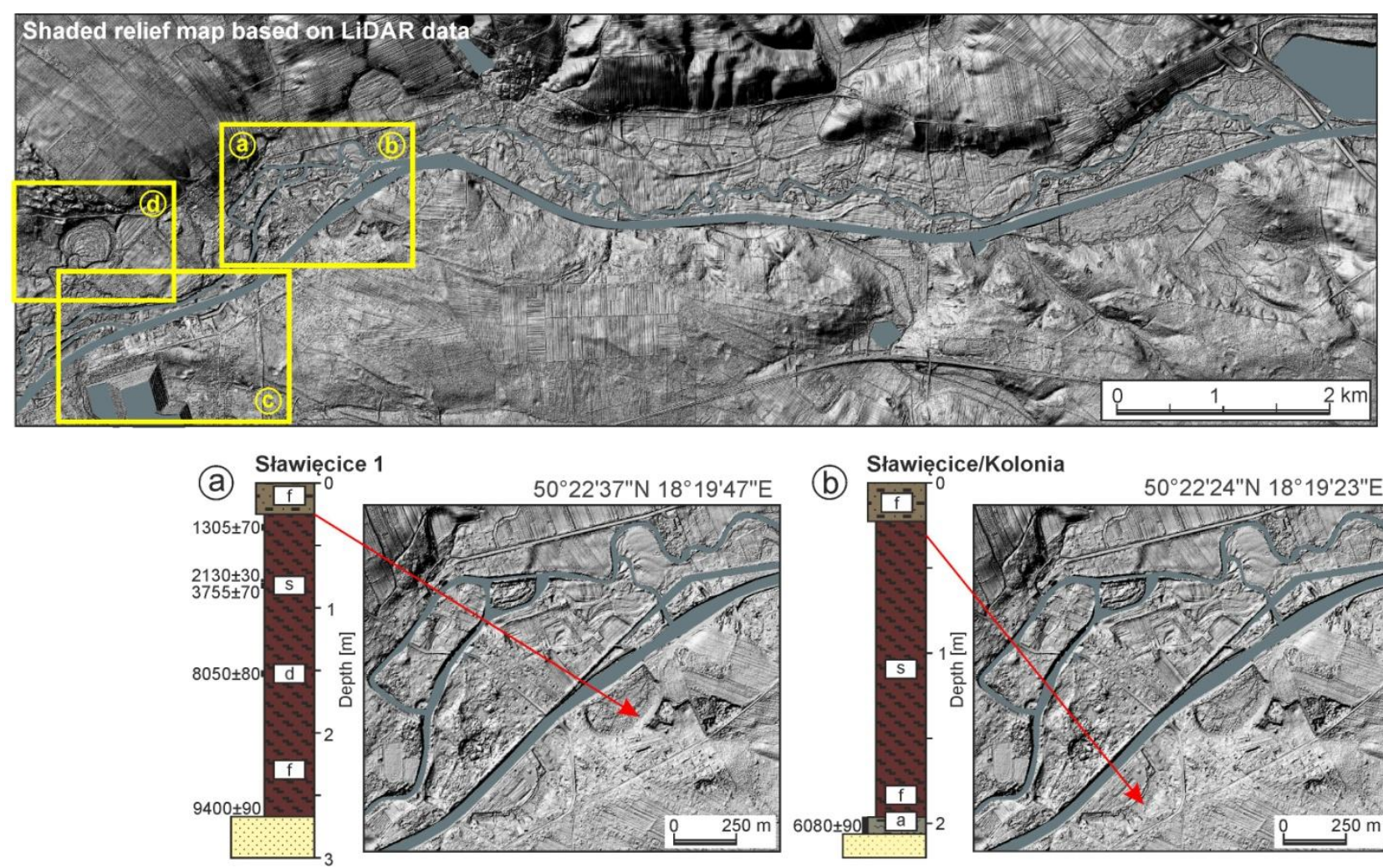

(b) Sławięcice/Kolonia

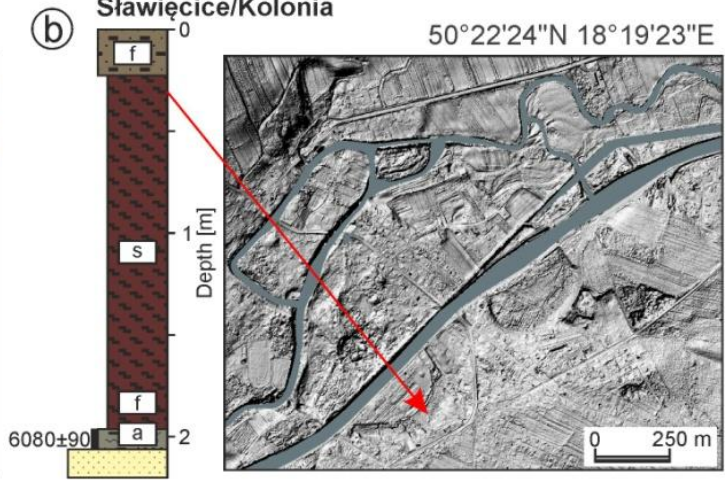

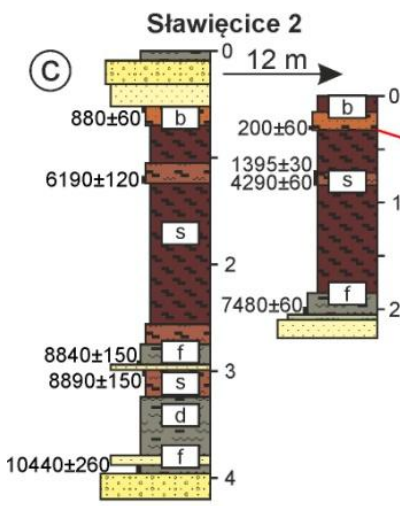

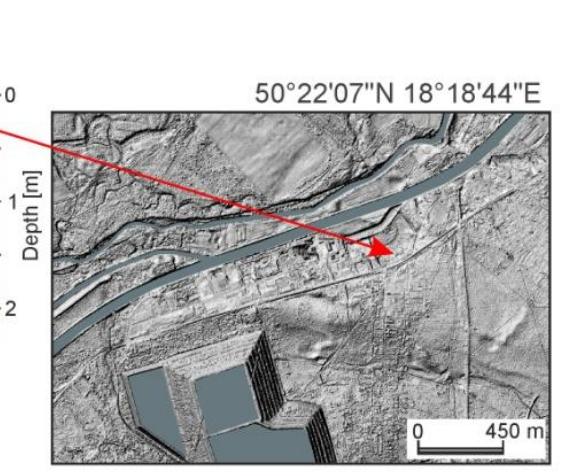

(d) Las Czajka

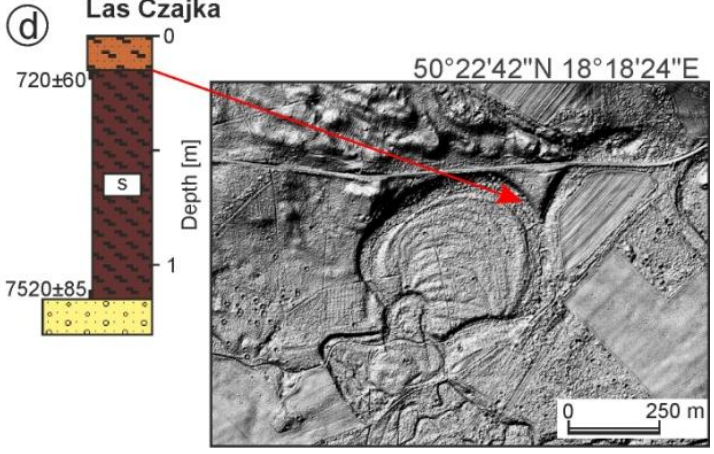

Stage of peatland development: main components of organic deposits:
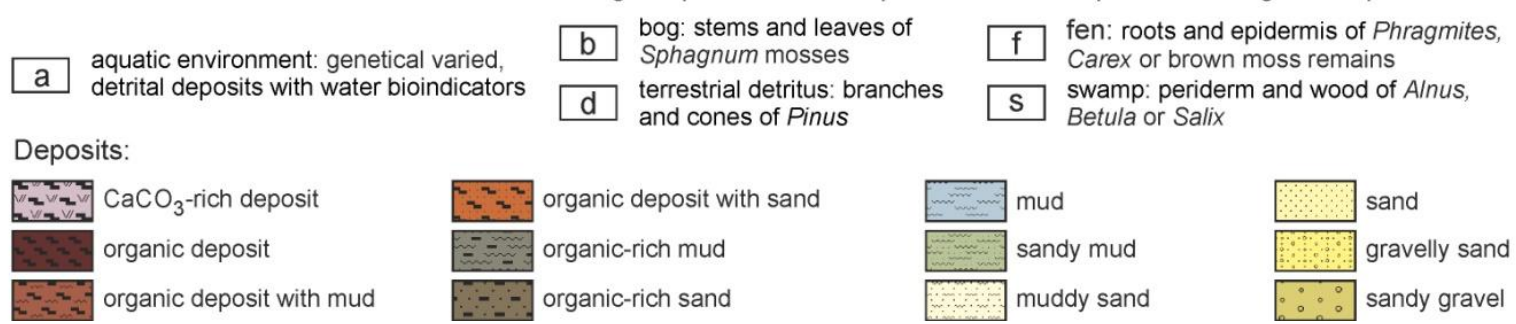

Fig. 4. Radiocarbon-dated sequences of the active wetland deposits (shaded relief map based on LiDAR data from CODGiK)

The domination of limno-telmatic conditions within the Sławięcice 1 peatland (Fig. 4a) is evidenced by macrofossils documenting the development of sedge-moss and common reed communities as well as swamp forest with prevailing black alder (Wójcicki, 2013). The initiation of peat-forming processes occurred as a result of meander cut off in the pre-Boreal. A substantial portion of the peat filling the depression was accumulated in the Early Holocene (NITA \& WóJCICKI, 2005). The fen surface was reduced as a result of the activity of slope processes initiated in the early Middle Ages $\left(1305 \pm 70{ }^{14} \mathrm{C}\right.$ yrs BP). Part of the mire where organic deposits were covered by sandy slope sediments was turned into a meadow. A similar history refers to the wetland designated as Sławięcice 2 (Fig. 4c). The limnotelmatic conditions are evidenced by, among others, the remains of Cladocerans and Chironomids, Bryozoan statoblasts and the remains of aquatic and peat-forming plants, including Sphagnum mosses (WóJCICKI, 2013). According to the results 
of radiocarbon dating, the history of organic accumulation in the deepest part of the sedimentary reservoir reaches the Late Glacial, while the initiation of peat-forming processes on the slope of the point bar occurred in the Atlantic phase of the Holocene. During the reservoir filling period, there were several episodes when organic accumulation was interrupted by fluvial and slope processes. The youngest period of sandy slope deposition which diminished the mire surface area was initiated in the early Middle Ages.

Mineral sedimentation only slightly influenced the peatland designated as Sławięcice/Kolonia (Fig. 4b). According to the radiocarbon dating, peat-forming processes were initiated in the Middle Holocene and are active to this day in connection with the development of the community of Phragmites australis. The common reed communities are also responsible for the modern accumulation of peat in small oxbow lakes cut off in recent decades. In turn, the development of the swamp in the area of Las Czajka (Fig. 4d) is indicated by wood peat dominated by the alder macrofossils. According to the results of radiocarbon dating, development of the peatland has continued since at least the Atlantic phase of the Holocene, which is probably favoured by its location in the forested area. Only the edge of the wetland experienced sedimentation of sandy sediments dated to less than $720 \pm 60{ }^{14} \mathrm{C}$ yrs BP.

\subsection{Changes to the range of wetlands between the second half of the $19^{\text {th }}$ century and the late $20^{\text {th }}$ century}

In the light of the analyses of topographic maps from the $19^{\text {th }}$ and $20^{\text {th }}$ centuries, wetlands occupied about 4.6 and $2.4 \%$ respectively of the surface area of the studied valley section (Fig. 5). The wetlands under consideration can be divided into two groups. In the distal zone of the valley bottom there are peatlands, described in the previous section, whose development was initiated in the earlier phases of the Holocene. Their area, covering approximately 15 ha, has remained almost unchanged during the last century. Late-Holocene wetlands develop sporadically in this zone. It may be partly related to drainage work. The maps from the $19^{\text {th }}$ century show a locally dense network of ditches that today drain about $15 \%$ of the valley bottom. In contrast, numerous wetlands are developing in the proximal zone of the valley bottom. They are genetically related with the youngest system of inset terraces and associated abandoned channels. Their geological probing revealed no presence of peat deposits, which inclines to classify them as non-peat forming wetlands. As a consequence of their disappearance, the wetland area in the valley bottom decreased from 64.3 ha in the second half of the $19^{\text {th }}$ century to 33.7 ha at the turn of the $20^{\text {th }}$ and $21^{\text {st }}$ centuries, i.e. by almost $48 \%$.

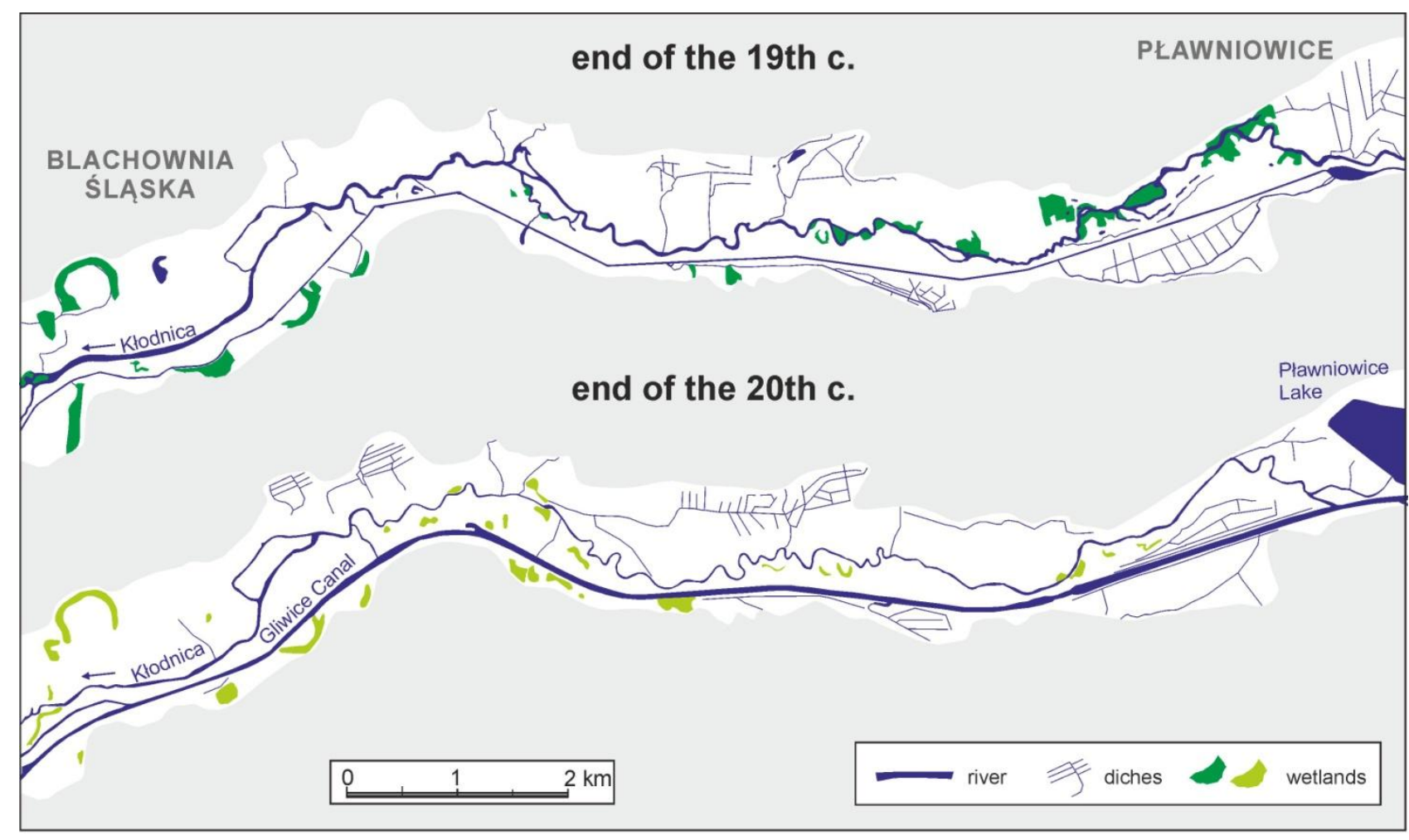

Fig. 5. Changes in the wetland areas since the end of the $19^{\text {th }}$ century 


\section{Discussion}

The study of spatio-temporal changes in the wetlands of Poland usually refer to the last 100-250 years. This results from the adopted research methodology based on the analysis of cartographic materials. The maps used should be reliable in terms of representation of spatial objects, and so are usually no older than the second half of the 18 century (e.g. OLACZEK ET AL., 1990; ŁAJCZAK, 2006; KOPROWSKI ET AL., 2012; JUCHA, 2014). The research procedure used in this project was based on lithological analyses and thus helped significantly extend the temporal range of the reconstructions carried out. The results indicate a trend towards gradual growth in the peaty area over the course of the Holocene (Fig. 6). This increase was related to the activity of the fluvial processes (the formation of new generations of oxbow lakes mainly), as well as expansion of existing peatlands. In the Middle Holocene, a transition phase of peat degradation, as a result of lowering the groundwater level, was observed in the Sławięcice 1 and Łany Małe cores (NiTA \& WóJCiCKI, 2005). Nevertheless, under natural conditions, the wetland loss rarely occurred. Increased overbank sedimentation dated to the Atlantic phase led to fossilisation of a small wetland at the Wydzierów site only.

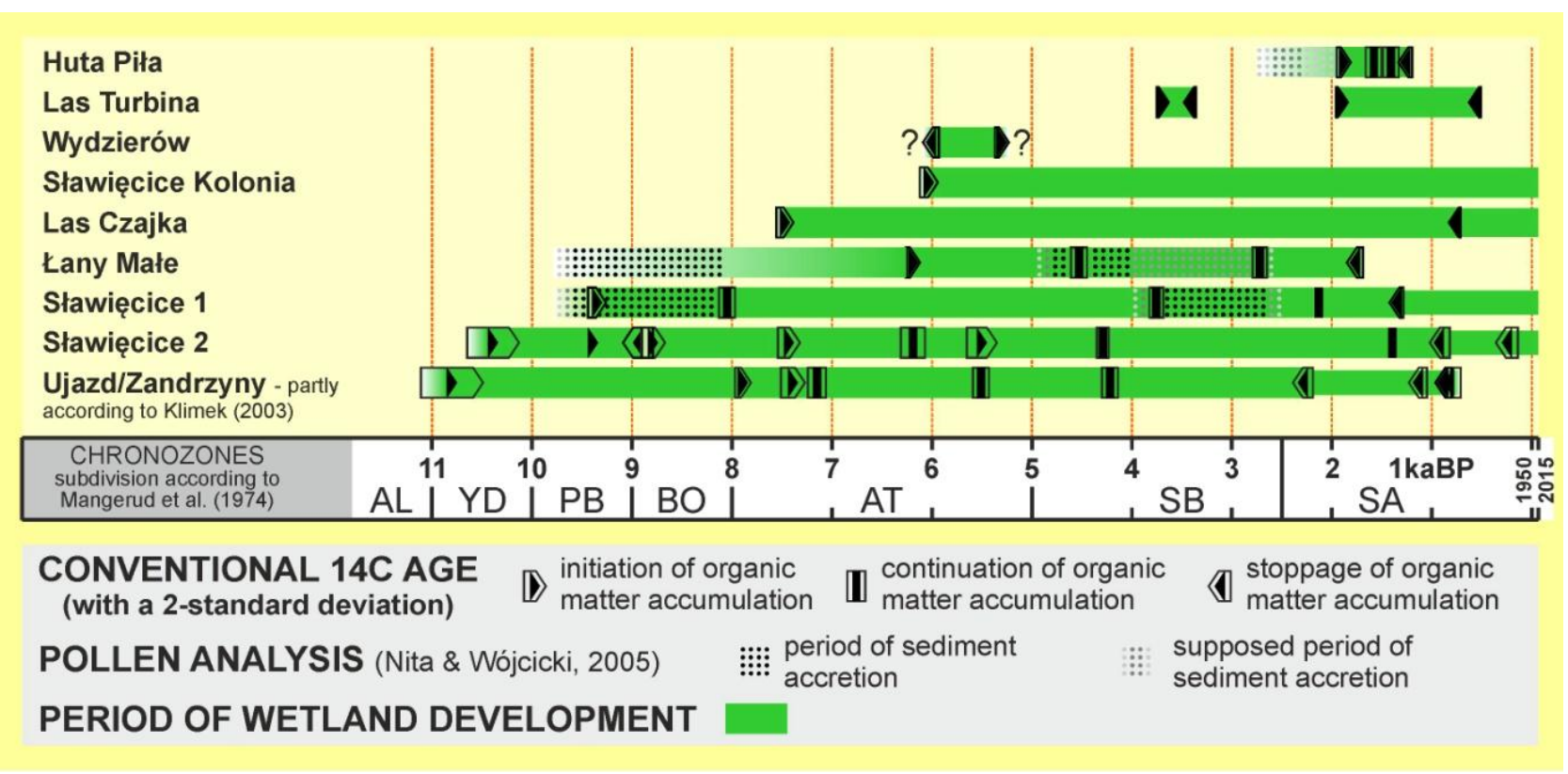

Fig. 6. Reconstructed periods of wetland development in the lower reach of the Kłodnica valley

The large scale disappearance of wetlands in the Kłodnica valley resulted from human impact. An overview of studies related to past centuries reveals several trends due to the direct human impact on wetlands. The most important reasons include drainage, usually carried out in order to acquire agricultural land or the conversion of natural tree communities into economic forest (CZACHOROWSKI, 1995; ŁAJCZAK, 2006; GAŁKA, 2007; KOPROWSKI ET AL., 2012; Jucha, 2014). Peat extraction is mentioned as often among the causes of the disappearance of the wetlands ( GAŁKA, 2007; Koprowski et al., 2012). Furthermore, according to CZACHOROWSKI (1995) and KOPROWSKI ET AL. (2012), man indirectly contributes to eutrophication and faster overgrowing of lakes due to the increased flow of nutrients from agricultural areas. These causes had little impact on the first stage of the disappearance of wetlands in the Kłodnica valley. Although the initiation of fossilisation of individual wetlands in this valley was not synchronous, in all cases it can be correlated with the phases of increased agricultural colonisation. This refers to the following settlement phases: the Lusatian culture between the $9^{\text {th }}$ and $3^{\text {rd }}$ centuries BC, Przeworsk culture between the $3^{\text {rd }}$ and $6^{\text {th }}$ centuries $A D$, early Middle Ages (ABŁAMOWICZ \& ŚNIESZKO, 2001) as well as the period covering the historical times starting from the medieval colonisation in the Duchy of Opole which intensified at the turn of the $13^{\text {th }}$ and $14^{\text {th }}$ centuries (PANIC, 1992). Direct evidence of the relationship between soil erosion and peatland fossilisation is provided by the Sławięcice 1 core, where mineral sedimentation was preceded by the appearance of synanthropic pollen (NITA \& WójCICKI, 2005). Increased sedimentation of the soil erosion products is responsible for decreasing 
the area of peat-forming wetlands from about 39 to about 15 ha in the studied section of the Kłodnica valley. Such fossilisation of valley peatlands was mentioned by ŻUREK (1987) as a common phenomenon in the territory of Poland.

The main reason for the most recent phase of change in wetland area in the Kłodnica valley is the transformation of the hydrographic network associated with the construction of the Kłodnica and Gliwice Canals as well as river regulation and channelization. As a consequence, numerous wetlands developed within the proximal floodplain (including oxbow lakes), which were depicted on topographic maps from the second half of the $19^{\text {th }}$ century. Probably the main reason for the disappearance of these small wetlands in the $20^{\text {th }}$ century was a strong down-cutting of the River Kłodnica as a reaction to straightening its course. On the other hand, lack of reactivation of wetlands in the distal zone of the valley floor could probably be associated with establishing a network of drainage ditches.

\section{Conclusions}

Identification of macrofossils - bioindicators of the limno-telmatic conditions, in conjunction with geological mapping and absolute dating, can be an effective tool for long-term (at the scale of millennia) reconstructions of changes in the extent of peatforming wetlands. It may, therefore, be a valuable addition to the short-term historical and cartographic analysis. The application of this methodology revealed that the origins of the waterlogging processes in the lower part of the Kłodnica valley should be attributed to the decline of the Late Vistulian. In the Holocene, the surface of the peatlands was generally increasing, reaching a maximum at the beginning of the sub-Atlantic phase. A key stage in the disappearance of peatforming wetlands in the Kłodnica valley started in the prehistoric period and was the result of increased mineral sedimentation in the valley bottoms conditioned by soil erosion. As a result, the surface area of active peatlands shrank by over $60 \%$. Quantitative changes were accompanied by a negative qualitative transformation. The share of non-peat forming wetlands increased relatively. What is more, these were ephemeral forms, whose trends and dynamics of development were strongly influenced by regulation of water conditions and the human economy. Consequently, in the last century further drying of almost $50 \%$ of wetlands took place as plotted on the maps from the $19^{\text {th }}$ century.

\section{References}

Abłamowicz D., Śnieszko Z. 2001. Osadnictwo kultur rolniczych w dorzeczu środkowej Kłodnicy a atrakcyjność krajobrazu. Sprawozdania Archeol., 53: 35-83.

Charman D., 2002. Peatlands and Environmental Change. John Wiley \& Sons Ltd. Chichester.

Czachorowski S. 1995. Zanikanie jezior i mokradeł. Ekopartner, 7/8 (45-46): 24-25.

Davidson N.C. 2014. How much wetland has the world lost? Long-term and recent trends in global wetland area. Marine and Freshwater Research, 65(10): 934-941.

Gałka M. 2007. Geograficzno-historyczne studium mokradeł południowo-wschodniej części ziemi świeckiej. Prace Zakł. Biogeogr. i Paleoekol. Uniw. im. A. Mickiewicza w Poznaniu, 7: 7-98.

Gardner R.C., Barchiesi S., Beltrame C., Finlayson C.M., Galewski T., Harrison I., Paganini M., Perennou C., Pritchard D.E., Rosenqvist A., Walpole M. 2015. State of the World's Wetlands and their Services to People: A compilation of recent analyses. Ramsar Briefing Note, 7, Gland, Switzerland: 1-21.

Jucha W. 2014. Zmiany sieci hydrograficznej w okolicach Puszczy Niepołomickiej w XX wieku zachowane na archiwalnych materiałach kartograficznych. Episteme, 22(2): 93-102.

Junk W.J., An S., Finlayson C.M., Gopal B., Květ J., Mitchell S.A., Mitsch W.J., Robarts R.D. 2013. Current state of knowledge regarding the world's wetlands and their future under global climate change: a synthesis. Aquatic Sci., 75(1): 151-167.

Klimek K. 2003. Sediment transfer and storage linked to Neolithic and Early Medieval soil erosion in the Upper Odra Basin, southern Poland. [in:] Howard A.J., Macklin M.G., Passmore D.G. (eds.) Alluvial Archaeology in Europe. Swets \& Zeitlinger, Lisse: 251-259.

Koprowski J., Łachacz A., Pieńkowski P., Szpigiel M. 2012. Przekształcenia śródpolnych mokradeł Pojezierza Dobrzyńskiego w świetle archiwalnych materiałów kartograficznych. Woda-Środowisko-Obszary Wiejskie, 12 (3): 123-138.

Kotlicki S., Kotlicka G.N. 1980. Objaśnienia do Mapy Geologicznej Polski 1:200000. Ark. Gliwice. Inst. Geol., Warszawa: 5-83.

Leadley P. W., Krug C.B., Alkemade R., Pereira H.M., Sumaila U.R., Walpole M., Marques A., Newbold T., Teh L.S.L, van Kolck J., Bellard C., Januchowski-Hartley S.R., Mumby P.J. 2014. Progress towards the Aichi Biodiversity Targets: An assessment of biodiversity trends, policy scenarios and key actions. Secretariat of the Convention on Biological Diversity. Montreal, Canada, Technical Series 78: 1-488.

Łajczak A. 2006. Torfowiska Kotliny Orawsko-Nowotarskiej. Inst. Botaniki im. W. Szafera PAN, Kraków.

Łajczak A. 2013. Zmniejszenie zasięgu złóż torfu i ich retencji wodnej w Kotlinie Orawsko-Nowotarskiej i w Bieszczadach w wyniku działalności człowieka. Przegl. Geol., 61(9): 532-540.

Mangerud J., Andersen S.T., Berglund B.E., Donner J.J. 1974. Quaternary stratigraphy of Norden, a proposal for terminology and classification. Boreas, 3: 109-128.

Nita M., Wójcicki K.J. 2005. Record of Holocene vegetation changes against a background of environmental conditions in the Kłodnica valley (southern Poland). Quaestiones Geogr., 24: 63-73.

Olaczek R., Kucharski L., Pisarek W. 1990. Zanikanie obszarów podmokłych i jego skutki środowiskowe na przykładzie województwa piotrkowskiego (zlewni Pilicy i Warty). Stud. Ośrodka Dokum. Fizjogr., 18: 141-199. 
Panic I. 1992. Historia osadnictwa $w$ księstwie opolskim we wczesnym średniowieczu. Rozprawy i studia Muzeum Śląskiego, Katowice.

Silva J.P., Phillips L., Jones W., Eldridge J., O'Hara E. 2007. LIFE and Europe's wetlands: restoring a vital ecosystem. Office for Official Publications of the European Communities, Luxembourg.

System Informacji Przestrzennej o Mokradłach Polski. Inst. Melioracji i Użytków Zielonych, Falenty, 2006.

Wójcicki K.J. 2010. The valley-fill deposits of the Kłodnica River (southern Poland): environmental drivers of facies changes from the Late Vistulian through the Holocene. Geochronometria, 35: 49-66.

Wójcicki K.J. 2013. Osady biogeniczne w środowisku depozycyjnym starorzeczy. Wyd. Uniw. Śląskiego, Katowice.

Wójcicki K.J., Kloss M. 2008. Makroszczątki roślinne w torfie w analizie paleośrodowiskowych uwarunkowań osadnictwa na przykładzie stanowiska Łane Małe $\mathrm{w}$ dolinie Kłodnicy. Stud. Ecologiae et Bioethicae, 6: 449-460.

Żurek S. 1987. Złoża torfowe w Polsce na tle stref torfowych Europy. Dokum. Geogr., 4. 